Удк 664.121

\title{
PRESERVATION OF TECHNOLOGICAL QUALITIES OF SUGAR BEET DURING HARVESTING AND STORAGE OF SUGAR BEET IS THE KEY FOR OBTAINING SUGAR OF HIGH QUALITY CATEGORIES
}

\author{
V. Mil'kevych \\ Institute of Post-Diploma Training of the National University of Food Technologies
}

\begin{tabular}{|c|c|}
\hline Key words: & ABSTRACT \\
\hline $\begin{array}{l}\text { root crop, } \\
\text { sugar beet, } \\
\text { technical ripeness, } \\
\text { sugar content, } \\
\text { harvesting methods, } \\
\text { ripeness coefficient }\end{array}$ & $\begin{array}{l}\text { The analysis of factors was made that affect the techno- } \\
\text { logical quality of sugar beets during its harvesting and storage. } \\
\text { Suggestions have been made to optimize technological proces- } \\
\text { ses that make it possible to reduce the weight loss of beets and } \\
\text { sugar, and maintain the technological qualities of sugar beets. } \\
\text { To provide sugar factories with benign raw materials in the }\end{array}$ \\
\hline $\begin{array}{l}\quad \text { Article history: } \\
\text { Received } 25.10 .2019 \\
\text { Received in revised form } \\
\text { 06.11.2019 } \\
\text { Accepted } 24.11 .2019 \\
\end{array}$ & $\begin{array}{l}\text { initial period of production in crops of sugar beets, it is neces- } \\
\text { sary to have early ripening hybrids. When organizing the stora- } \\
\text { ge of sugar beets in the field, it is necessary to observe the } \\
\text { technology of its storage as at the factory beet reception centers. } \\
\text { The total loss of sucrose in root crops during storage is }\end{array}$ \\
\hline $\begin{array}{l}\text { Corresponding author: } \\
\text { sugar_ipdo@ukr.net }\end{array}$ & $\begin{array}{l}\text { mainly due to biological processes that are associated with the } \\
\text { respiration of root crops and microbiological processes that dep- } \\
\text { end on the physical condition of the root crops, storage condi- } \\
\text { tions and shelf life, and the size of the cut of the root head. } \\
\text { To reduce the loss of sucrose during storage, gravity ventila- } \\
\text { tion of root crops using air is used, using the trays of the opera- } \\
\text { ting hydraulic conveyors for this pur-pose, after overlapping } \\
\text { them with grates. } \\
\text { Due to the constant movement of air through the channel of } \\
\text { the hydraulic conveyor, the temperature in the blades is lower } \\
\text { than in the blades laid near the tray of the hydraulic conveyor, } \\
\text { the intensity of respiration and the loss of sucrose are reduced. } \\
\text { To prevent and reduce the effects of blight rot, it is advisable } \\
\text { to sugar beets during the growing season, root crops during sto- } \\
\text { rage, treated with biocidal preparations, use fungicide - lignite. } \\
\text { Fungicide inhibits bacteria, mold fungi, inhibits enzymes that } \\
\text { decompose sugar. Protective actions are from } 90 \text { to } 120 \text { days. } \\
\text { The drug accompanies the accumulation of sugar in root crops, } \\
\text { due to the activation of the outflow of nutrients from leaves to } \\
\text { root crops. }\end{array}$ \\
\hline
\end{tabular}

DOI: $10.24263 / 2225-2916-2019-26-6$

(C) В. М. Мількевич, 2019 


\section{ЗБЕРЕЖЕННЯ ТЕХНОЛОГІЧНИХ ЯКОСТЕЙ ЦУКРОВИХ БУРЯКІВ ПІД ЧАС ЗБИРАННЯ І ЗБЕРІГАННЯ - ЗАПОРУКА ОДЕРЖАННЯ ЦУКРУ ВИСОКИХ КАТЕГОРІЙ ЯКОСТI}

В. М. Мількевич, канд. техн. наук

Інститут післядипломної освіти Національного університету харчових технологій

У статті проаналізовано фрактори, які впливають на технологічну якість цукрових буряків при їх збиранні і зберіганні. Внесено пропозиції щодо оптимізації технологічних процесів, які надають можливість зменшити псування коренеплодів $i$ зберегти технологічні якості вирощених цукрових буряків. Розроблено рекомендації, які надають можливість покращити ведення технологічних операцій бурякосіючими господарствами і иукровими заводами, зменшити втрати маси буряків $i$ цукру та зберегти їхні технологічні якості. Показано, що для забезпечення цукрозаводів доброякісною сировиною в початковий період виробництва доцільно використовувати сорти скоростиглих гібридів иукрових буряків. Доведено, що загальні втрати иукрози в коренеплодах при зберіганні обумовлені, в основному, біологічними процесами, пов'язаними з диханням коренеплодів і мікробіологічними процесами, які залежать від їх фрізичного стану, умов і термінів зберігання, величини зрізу гички та головки буряка, а механічні пошкодження коренеплодів $\epsilon$ одним із основних фракторів, які впливають на втрату иукрози при диханні. Показано важливість оброблення иукрових буряків біоцидними засобами, зокрема фунгіцидом «Кагатник».

Ключові слова: коренеплід, иукровий буряк, технічна стиглість, вміст иукру, способи збирання, коефріцієнт стиглості.

Постановка проблеми. Для одержання цукру високих категорій якості необхідно мати якісну сировину. Вирішення проблем збирання, зберігання коренеплодів та їх технологічних якостей під час перероблення для України залишається актуальним. Одночасно з цим важливим напрямком обмеження втрат біологічної продукції і підвищення виходу цукру є обмеження загальних термінів переробки.

Метою статті $є$ узагальнення сучасних підходів до питань збирання та зберігання цукрових буряків. Матеріали і методи. 3 метою оцінки зменшення втрат маси буряків і цукру, недопущення погіршення їхніх технологічних якостей була вивчена технологія використання для укриття поверхні кагатів 3 буряками нетканого полотна Toptex (виробництво Австрія), а також фунгіциду «Кагатник» ВРК (виробництво «Щолково-Агрохім», Росія). В дослідження коренеплоди оброблялись 60 мл « Кагатника», попередньо розведеними до 3 л/т коренеплодів.

Для визначення втрат маси буряків і цукру після їх зберігання використовувалась методика закладання в кагати сіткових проб буряків у сітках, поверхня яких була вкрита і невкрита нетканим полотном (напівпромислові дослідження). Також досліджувалися буряки в сітках, закладених в кагати, вкритих і невкритих очеретяними матами. Закладались у кагати сітки, коренеплоди в яких були оброблені і необроблені «Кагатником». Буряки обробляли фунгіцидом за допомогою ручного обприскувача.

Дослідження в промислових умовах передбачали об'ємну обробку цукрових буряків під час укладання їх на зберігання робочим розчином препарату за 
допомогою серійної установки для об’ємної обробки поверхні буряків Ш1-ПОХ, якою обладнали мобільний кагатоукладчик.

Формування сіткових проб, визначення середньодобових втрат цукру та бурякової маси при зберіганні, фітопатологічні й аналітичні аналізи виконували за прийнятими у цукровій промисловості методиками.

Викладення основних результатів дослідження. Для одержання цукру, здатного конкурувати на зовнішніх ринках, потрібна високоякісна сировина. Головним завданням під час збирання і зберігання буряків $є$ збереження вихідних технологічних якостей коренеплодів, одержаних під час вегетації.

Важливим у проведенні кампанії перероблення сировини є вибір оптимальних термінів збирання цукрових буряків, при цьому слід враховувати: очікуваний урожай, технічну стиглість коренеплодів, наявність бурякозбиральної техніки, автотранспорту, буртоукладачів, добові потужності цукрозаводів, метеофактори [1].

Узагальнення цих технологій дає змогу стверджувати, що при плануванні збирання врожаю цукрових буряків слід враховувати, що приріст маси коренеплодів і цукру в них у першій половині вересня, як правило, не збільшує втрати маси буряків та цукру при збільшені періоду збирання і перероблення їх до груднясічня, і це підтверджується багаторічним досвідом. Адже відомо, що на початку сезону перероблення буряків вихід цукру на $3 . . .4 \%$ більший, ніж у грудні-січні.

На якість цукрових буряків значною мірою впливають терміни збирання (табл. 1).

3 метою визначення черговості збирання полів залежно від стану буряків, розміщення їх на категорії зберігання на цукрозаводі або в польових умовах перед початком збирання доцільно зробити суцільне фітопатологічне обстеження коренеплодів на всіх площах і скласти графіки збирання, вивезення та перероблення.

На час збирання буряки повинні бути технічно стиглі, мати коефіцієнт стиглості - 0,6...0,7 при непошкодженому листовому апараті, МБ-фактор - 25...30, максимальну кількість цукру і мінімальну нецукрів, високу доброякісність клітинного соку. Приймання і розрахунки чергової партії цукрового буряку необхідно здійснювати 3 урахуванням хімічного складу коренеплодів. Буряки, зібрані у жовтні, мають кращі технологічні показники (урожайності, цукристості і хімічного складу), ніж ті, що зібрані у вересні.

Таблиия 1. Продуктивність і якість цукрових буряків залежно від термінів збирання [2]

\begin{tabular}{|l|c|c|}
\hline \multirow{2}{*}{ Показник } & \multicolumn{2}{|c|}{ Термін збирання } \\
\cline { 2 - 3 } & 14 вересня & 1 жовтня \\
\hline Урожайність коренеплодів, т/га & 34,0 & 37,3 \\
\hline Цукристість, \% & 18 & 18,7 \\
\hline Збір цукру, т/га & 6,2 & 7,0 \\
\hline Вміст у коренеплодах, \%: & - & - \\
\hline калію & 0,209 & 0,160 \\
натрію & 0,038 & 0,030 \\
L- амінного азоту & 0,076 & 0,040 \\
\hline Чистота очищеного соку, \% & 93,1 & 94,5 \\
\hline Розрахунковий вихід цукру, \% & 15,4 & 16,1 \\
\hline Розрахунковий вихід цукру, т/га & 5,2 & 6,0 \\
\hline
\end{tabular}

Для забезпечення цукрозаводів доброякісною сировиною в початковий період виробництва для посіву цукрових буряків необхідно мати сорти скоростиглих 
гібридів. Для зменшення витрат на транспортування буряків при значних відстанях бажано вирощувати гібриди типу Z i ZZ (цукристий і максимально цукристий) [3]. При плануванні оптимального завантаження цукрозаводу сировиною важливо визначитись із термінами початку і закінчення їі переробки.

При інтенсивному зневодненні коренеплодів втрата кожного відсотка вологи може призвести до збільшення середньодобових втрат цукрози на 0,005...0,01\% до маси буряків. При ранніх термінах збирання (початок вересня) на перероблення надходять буряки технічно незрілі, 3 низькою цукристістю і великою кількістю нецукрів. Коренеплоди мають низьке водоутримання, схильні до в'ялення з подальшим гниттям (табл. 2). При запізненні з початком збирання виникає загроза ураження врожаю слизистим бактеріозом і зниження якості буряка (табл. 3).

Таблиия 2. Результати аналізу коренеплодів цукрових буряків (свіжовикопаних і підв'ялених), які зберігалися протягом 60 діб [3]

\begin{tabular}{|c|c|c|c|}
\hline $\begin{array}{c}\text { Коренеплоди } \\
\text { цукрових буряків }\end{array}$ & $\begin{array}{c}\text { Втрати цукрози, \% } \\
\text { до маси буряків }\end{array}$ & $\begin{array}{c}\text { Зменшення чистоти } \\
\text { бурякового соку, \% }\end{array}$ & $\begin{array}{c}\text { Маса коренеплодів, що } \\
\text { загнили, \% }\end{array}$ \\
\hline Свіжі викопані & 1,3 & 1,8 & Немає \\
\hline \multicolumn{4}{|c|}{ Втратили вологу, \% } \\
\hline 7 & 3,4 & 4,6 & 37 \\
\hline 13 & 6,1 & 11,3 & 65 \\
\hline 17 & 7,1 & 12,6 & 96 \\
\hline 28 & 8,9 & 16,8 & \\
\hline
\end{tabular}

Таблиия 3. Хімічний склад і технологічні якості цукрових буряків, уражених слизистим бактеріозом [4]

\begin{tabular}{|c|c|c|c|c|c|c|}
\hline \multirow{2}{*}{ Якість буряків } & \multirow{2}{*}{$\begin{array}{c}\text { Вуміст } \\
\text { цукру, \% }\end{array}$} & \multirow{2}{*}{$\begin{array}{c}\text { Редукуючі } \\
\text { деч. б. }\end{array}$} & \multicolumn{5}{|c|}{ рормальний сік } \\
\cline { 3 - 7 } & & PH & СР, \% & $\begin{array}{c}\text { Цукри- } \\
\text { стість, \% }\end{array}$ & $\begin{array}{c}\text { Чистота } \\
\text { соку, \% }\end{array}$ \\
\hline Здорова маса, \% & 17,2 & 0,134 & 6,02 & 22,75 & 19,0 & 85,52 \\
\hline $\begin{array}{c}\text { Здорова+гнила } \\
\text { маса, \% }\end{array}$ & \multicolumn{7}{|l|}{} \\
\hline 10 & 16,9 & 0,365 & 5,50 & 22,6 & 17,2 & 76,11 \\
\hline 25 & 15,1 & 0,473 & 5,45 & 22,1 & 11,4 & 51,58 \\
\hline 50 & 12,3 & 0,934 & 4,75 & 22,0 & 10,8 & 49,09 \\
\hline 75 & 9,0 & 1,586 & 4,60 & 20,8 & 9,0 & 43,27 \\
\hline 100 & 5,1 & 3,691 & 4,45 & 20,7 & 7,2 & 34,78 \\
\hline
\end{tabular}

Коли маса вимороженої води в тканині буряка досягає $45 \%$, руйнуються клітинні стінки і всередину клітини проникають бактерії Leuconostok mesenteroides, які викликають слизистий бактеріоз. При 10\% гнилої маси коренеплоди непридатні для одержання білого цукру.

Погодні умови 2015-2017 pр. сприяли збиранню цукрових буряків у листопаді місяці, Це дало змогу підприємствам працювати з високими технікотехнологічними показниками на відміну від 2018 р., коли в листопаді мало місце зниження температури до мінусових показників, підморожування коренеплодів 3 подальшим ураженням їх слизистим бактеріозом.

Викопані і неперероблені цукрові буряки потрібно зберігати або на призаводських бурякопунктах, або в польових умовах. При організації польового кагатування необхідно додержуватись такої технології їх зберігання, як на призаводських бурякопунктах. Зокрема, це підготовка підкагатних площадок, захист 
коренеплодів у кагатах від негативних факторів зовнішнього середовища, обробка поверхні кагатів вапняним розчином, укриття кагатів різними матеріалами (нетканим полотном, солом'яними, очеретяними матами, землею, гичкою).

Втрати маси буряків і цукру, особливо в умовах неоптимальних температур під час їх зберігання, можуть бути значними; величина цих втрат залежить від захисту коренеплодів від негативних факторів зовнішнього середовища (див. табл. 4).

Табличя 4. Втрати маси буряків і цукру при різних способах польового зберігання [5]

\begin{tabular}{|c|c|c|c|c|c|c|}
\hline \multirow[t]{2}{*}{$\begin{array}{c}\text { Способи польового } \\
\text { зберігання }\end{array}$} & \multicolumn{4}{|c|}{$\begin{array}{c}\text { Втрати маси буряків, \% при } \\
\text { різних термінах зберігання, діб }\end{array}$} & \multicolumn{2}{|c|}{$\begin{array}{c}\text { Втрати цукрози, \% від } \\
\text { вихідного вмісту при різних } \\
\text { термінах зберігання }\end{array}$} \\
\hline & 3 & 5 & 10 & 15 & 10 & 15 \\
\hline $\begin{array}{c}\text { Кагати вкриті: } \\
\text { землею на } 20 \ldots 25 \text { cм }\end{array}$ & 0,8 & 1,5 & 2,5 & 4,2 & 0,42 & 0,72 \\
\hline нетканим полотном & 1,1 & 1,9 & 4,1 & 5,2 & 0,50 & 0,81 \\
\hline солом'яними матами & 1,7 & 2,5 & 5,4 & 7,7 & 0,63 & 1,01 \\
\hline гичкою на 20 см & 2,1 & 3,4 & 7,1 & 10,4 & 0,77 & 1,24 \\
\hline Кагати без укривання & 3,8 & 5,6 & 9,9 & 16,8 & 1,31 & 1,83 \\
\hline Валки без укривання & 4,4 & 6,1 & 11,5 & 17,9 & 1,70 & 2,21 \\
\hline
\end{tabular}

Корені під нетканим полотном не пітніють у зв'язку з властивістю тканини створювати оптимальну циркуляцію повітря. Вони дихають, відбувається позитивний газообмін 3 навколишнім середовищем, разом 3 тим полотно не пропускає опади всередину кагату. Тканина Тoptex значно зменшує перепади температур всередині кагату на фоні таких перепадів на поверхні. При температурі $10^{\circ} \mathrm{C}$ полотно обмежено захищає буряки в кагаті від підморожування. Самий верхній шар буряків, який контактує 3 покриттям, підмерзає, решта буряків зберігає свою кондиційність.

3 табл. 4 видно, що втрати маси буряків і цукру менші при укритті коренеплодів землею і легким у використанні нетканим полотном. Не рекомендується укривати кагати подрібненою соломою, тому що вона погано уловлюється на тракті подачі буряків, погіршує якість бурякової стружки.

Основний спосіб збирання цукрових буряків - потоковий - забезпечує високу якість сировини при сприятливих погодних умовах, менші втрати і пошкодження коренеплодів. Перевалочний спосіб збирання потрібно використовувати в екстремальних умовах: дуже вологий, сухий або твердий грунт, підвищена забур'яненість поля, ворох, значно забруднений землею, рослинними залишками та при наявності в грунті гнилих коренеплодів.

У голівці коренеплоду знаходиться до 12\% нецукрів, тоді як в основній частині кореня - до 6\%. Налагодження бурякозбиральної техніки на оптимальний зріз головки (до 1 см залежно від ступеня розвитку коренеплоду) надасть можливість підвищити доброякісність очищеного соку, збільшити вихід цукру, зменшити витрати буряків на одержання 1 т цукру та витрати виробничих матеріалів.

Відвантаження коренів з польових кагатів необхідно здійснювати суворо за графіком, який повинен збігатися з графіком їх переробки на цукрозаводі, оскільки буряки, які зберігалися в польових кагатах, вдруге зберіганню на цукрозаводі не підлягають. Коренеплоди після збирання для підтримки життєдіяльності використовують власні запаси метаболітів, зокремацукру, в них відбуваються зміни 
хімічного складу. Головне завдання при зберіганні цукрових буряків - зберегти технологічні якості, отримані під час їх вирощування.

Загальні втрати цукрози в коренеплодах при зберіганні обумовлені в основному біологічними процесами, які пов'язані з диханням коренеплодів і мікробіологічними процесами ітазалежать від фізичного стану коренеплодів, умов і термінів зберігання, величини зрізу гички та голівки коренеплоду.

Відразу після надходження буряків на зберігання втрати цукрози, в основному, пов'язані з диханням. При збільшенні термінів зберігання коренеплодів втрати цукрози на $80 \ldots 90 \%$ залежать від розвитку мікробіологічних процесів, які супроводжуються утворенням гнилі. Інтенсивному диханню буряків сприяє їх механічне пошкодження (табл. 5).

Порівнюючи зі стабілізованою величиною, яку приймають за 100\%, інтенсивність дихання механічно пошкоджених коренеплодів в перші дві доби після зберігання була у $2-3$ рази більшою. Після 8 діб інтенсивність дихання в основному стабілізувалась, пройшло зарубцювання (суберенізація) пошкодженої поверхні тканини.

Таблиия 5. Інтенсивність дихання коренеплодів залежно від характеру пошкоджень і терміну зберігання [4]

\begin{tabular}{|c|c|c|c|c|c|c|c|c|}
\hline Характер & \multicolumn{6}{|c|}{ Інтенсивність дихання, \% до стабілізованого стану, за добу } \\
\cline { 2 - 9 } \\
\cline { 2 - 8 } коренеплодів & 1 & 2 & 3 & 4 & 5 & 6 & 7 & 8 \\
\hline $\begin{array}{c}\text { Без значних } \\
\text { механічних } \\
\text { пошкоджень }\end{array}$ & 170 & 204 & 195 & 160 & 145 & 120 & 113 & 105 \\
\hline $\begin{array}{c}\text { 3 відбитим боком і } \\
\text { частково головкою }\end{array}$ & 299 & 291 & 210 & 205 & 190 & 165 & 158 & 140 \\
\hline 3 відбитою голівкою & 270 & 326 & 305 & 250 & 200 & 170 & 140 & 125 \\
\hline $\begin{array}{c}\text { 3 відбитою боковою } \\
\text { частиною }\end{array}$ & 230 & 240 & 192 & 169 & 150 & 128 & 119 & 106 \\
\hline Розрізані впродовж & 329 & 290 & 273 & 240 & 210 & 190 & 180 & 165 \\
\hline Одержані по 8 ударів & 377 & 350 & 290 & 249 & 212 & 198 & 185 & 176 \\
\hline $\begin{array}{c}\text { Одержані різні види } \\
\text { ударів }\end{array}$ & 297 & 303 & 255 & 221 & 194 & 172 & 154 & 144 \\
\hline
\end{tabular}

Примітка: Стабілізована величина $=100$.

Таким чином, механічні пошкодження буряків є одним із основних факторів, які впливають на втрату цукрози при диханні. Тому необхідно зменшувати механічні пошкодження цукрових буряків на всіх етапах: під час збирання, навантаження, при укладанні буряків в кагати, при подачі на виробництво.

У перший період зберігання необхідно створювати умови для швидкого заживлення пошкоджень коренеплодів, що призведе до зменшення інтенсивності дихання. Для зниження температури всередині кагату та інтенсивності дихання застосовують вентилювання коренеплодів зволоженим повітрям. Це зменшує втрати цукрози на $15 . .20 \%$, порівняно зі зберіганням без вентилювання.

За відсутності майданчиків 3 активним вентилюванням ряд цукрозаводів застосовує самопливну вентиляцію коренеплодів повітрям, використовуючи для цього діючі гідротранспортери (ТОВ «Новомиргородський цукор»; ВАТ «КаіндаКант», республіка Киргизія). Після перекриття гідротранспортера решітками 
(лядами), буряки укладають на гідротранспортер і формують кагат. При такому зберіганні за рахунок постійного руху повітря по каналу гідротранспортера температура в кагаті нижча, ніж у кагатах, укладених біля лотка гідротранспортера. Це дає змогу зменшити інтенсивність дихання коренеплодів та втрати цукру; при подачі буряків у виробництво зменшити механічне пошкодження коренеплодів; зменшити втрати маси буряків удвічі, оскільки 40\% коренеплодів після видалення решіток самопливом поступає в гідротранспортер без застосування механізмів для подачі їх на завод.

Забрудненість буряків землею, зеленою масою залежить від способу збирання і погодних умов. При вологості грунту понад 23\% і забрудненості більше $20 \%$ буряки втрачають властивість сипучості. За рівня забрудненості 10\% бурякоукладачі відокремлюють лише $10 \ldots 25 \%$ домішок, інші домішки надходять у кагати або на перероблення. Частково буряки поступають на виробництво безпосередньо з транспортних засобів, тому їх навантаження 3 польових кагатів необхідно здійснювати навантажувачами 3 доочищувачами типу РОПА. При потраплянні зв'язаних 3 коренеплодом домішків у кагат зменшується міжкореневий простір, це сприяє виникненню анаеробного дихання буряків і є причиною одержання дифузійного соку низької якості. Зелена маса зменшує чистоту продуктів, на кожні 3\% зеленої маси вихід цукру зменшується на 0,3\%.

В'янення коренеплодів відбувається при ранніх термінах збирання, при несприятливих погодних умовах (висока температура і низька відносна вологість повітря, інтенсивна сонячна радіація). Об'єм буряків, які знаходяться в поверхневому шарі кагату (висота $3 \ldots 3,5$ м, ширина $12 \ldots 15$ м, на глибині 0,5 м), складає до 35\% від всієї кількості буряків. У таких умовах зберігання коренеплоди поверхневого шару втрачають за добу до 1\% маси і 0,2\% цукрози.

Шляхи вирішення проблеми - своєчасно вивозити і переробляти зібрані коренеплоди, поверхні кагатів обробляти вапняним розчином, буряки зберігати в більш об'ємних кагатах. Буряки, зібрані в більш пізні терміни, зберігати на призаводських бурякопунктах.

Для зменшення дії кагатної гнилі буряки під час укладання на зберігання доцільно обробляти біоцидними препаратами. 3 цією метою в Білорусі та Росії застосовують фунгіцид «Кагатник» [6]. Завдяки його антисептичній дії препарат позитивно впливає на лежкоздатність і зберігання технологічних якостей цукрових буряків. Препарат пригнічує бактерії, плісняві гриби, пригнічує ферменти, які руйнують цукри. Його захисна дія - 90..120 днів. Препарат виготовляє ЗАТ «Щолково-Агрохім», Росія. «Кагатник» може застосовуватись для боротьби 3 гнилями коренеплодів і вегетуючих рослин [6].

Висновки. Збирання цукрових буряків необхідно проводити в оптимальні терміни, першочерговим фактором при збиранні повинен бути фактор технічної стиглості буряків.

Для першого періоду виробництва при посівах цукрових буряків, бажано мати сорти скоростиглих гібридів.

Потрібно зменшувати механічні пошкодження коренеплодів на всіх етапах: збиранні, навантаженні, розвантаженні, подачі їх у виробництво.

Для зниження температури в кагатах за рахунок природної вентиляції застосовувати укладання кагатів з буряками на лотки гідротранспортерів. 
Для зменшення дії мікроорганізмів на коренеплоди під час вегетації буряків і при укладанні коренеплодів на зберігання, застосовувати біоцидні препарати, зокрема фунгіцид «Кагатник».

При переробці буряків у більш пізні терміни бажано зберігати їх на призаводських бурякопунктах. Додержання технологій збирання, зберігання цукрових буряків дасть змогу забезпечити цукрозаводи високоякісною сировиною.

\title{
ЛITЕРАТУРА
}

1. Роїк М. В. Управління технологічними процесами вирощування цукрових буряків / М. В. Роїк, В. М. Сінченко. - Вінниця: «Нілан ЛТД», 2013. — и38 с.

2. Чернявская Л. И. Пути снижения потерь сахарозы при переработке сахарной свеклы: материалы научно-технического семинара / Л. И. Чернявская. - Киев: ИПЦА ЛКОН, 2006. - 8 с.

3. Хелемский М. 3. Технологические качества сахарной свеклы / М. 3. Хелемский Москва: Пищевая промышленность, 1973. - 253 с.

4. Сахарная свекла: проблемы повышения технологических качеств и эффективности переработки / Чернявская Л. И., Ионицой Ю. С., Штангеев В. О., Милькевич В. М. и др. - Киев: Фитосоциологический центр, 2003. — 308 с.

5. Сахарная свекла. Выращивание, уборка, хранение / Шпар Д., Дрегер Д. и др. Москва: UD 000 «DLV Агродело», 2013. — 412 с.

6. Инновационный продукт нового поколения / Н. М. Сапронов // Сахарная свекла. - № 7. - 2013. - С. 16-18.

\section{СОХРАНЕНИЕ ТЕХНОЛОГИЧЕСКИХ КАЧЕСТВ САХАРНОЙ СВЕКЛЫ ПРИ СБОРЕ И ХРАНЕНИЕ - ЗАЛОГ ПОЛУЧЕНИЯ САХАРА ВЫСОКИХ КАТЕГОРИЙ KАЧЕСТВА}

\author{
В. М. Милькевич \\ Институт последипломного образования \\ Национального университета пищевых технологий
}

Выполнен анализ фракторов, влияющих на технологическое качество сахарной свеклы при ее сборе и хранении. Внесены предложения по оптимизации технологических процессов, позволяющих уменьшить порчу корнеплодов и сохранить технологические качества выращенной сахарной свеклы. Показано, что для обеспечения сахарных заводов доброкачественным сырьем в начальный период производства целесообразно использовать сорта скороспелых гибридов сахарной свеклы. Доказано, что общие потери сахарозы в корнеплодах при хранении обусловлены в основном биологическими процессами, связанными с дыханием корнеплодов и микробиологическим процессами, которые зависят от их фризического состояния, условий и сроков хранения, величины среза ботвы и головки свеклы, а механические повреждения корнеплодов являются одним из основных фракторов, влияющих на потерю сахарозы при дыхании. Показана важность обработки сахарной свеклы биоцидными средствами, в частности фрунгицидом «Кагатник».

Ключевые слова: корнеплод, сахарная свекла, техническая спелость, содержание сахара, способы уборки, коэфффициент спелости. 